En 1959, el profesor Carry no aceptó ser reelegido miembro del Comité Internacional de la Cruz Roja, pues su estado de salud y sus ocupaciones profesionales le impedían colaborar en la Institución con la misma entrega que en el pasado. El Comité Internacional se inclinó ante esta decisión, $y$, reconociendo los servicios prestados a la obra de la Cruz Roja, le nombró en su sesión del 8 de enero de 1959, miembro honorario. Como tal, el profesor Carry fue consultado con frecuencia y su parecer tenía mucha autoridad.

El Comité Internacional se ha enterado con mucho pesar de su fallecimiento y presenta a su familia su sincero pésame.

\title{
Alta distinción de la Cruz Roja Sueca al señor Gallopin
}

El señor Roger Gallopin, ex presidente del Consejo Ejecutivo del CICR, recibió la Medalla Real de oro de la Cruz Roja Sueca, la más alta distinción que confiere esa Sociedad.

El presidente de la Cruz Roja Sueca, señor Matts Bergon Larsson, escribe al señor Gallopin, en la carta en que le anuncia la condecoración: " Su personalidad y su posición le han permitido ejercer una extraordinaria influencia, durante muchos años, en nuestro movimiento y en diversos ámbitos de la actividad de la Cruz Roja... Se le confiere, ahora, nuestra más alta distinción como agradecimiento por sus notables contribuciones a la actividad humanitaria y con la esperanza de verlo aún participar, en la dirección del movimiento de la Cruz Roja ». 